\title{
Coordinated Governance in the VUCA Scenario
}

\section{Oscar Mauricio Covarrubias Moreno*}

\author{
https://doi.org/10.31297/hkju.21.3.6 \\ UDK $\quad 351.78 .01$ \\ 330.163.12:616.98 \\ 3.077.6:616.98 \\ Review article / pregledni znanstveni rad \\ Received / primljeno: $\quad$ 22.12. 2020. \\ Accepted / prihvaćeno: $\quad$ 4. 6. 2021.
}

This article deals with coordination in the study and practice of governance. Facing the new generation of complex public problems will require not only greater coordination, but also coordination that can only be built from a longterm systemic and global vision, based on governments with effective institutional capacity. In other words, internal sufficiency and external connectivity will be two key factors in the new governance. The article is structured in six sections. After the introduction, the second one analyses the concept of governance in terms of coordination. The third reviews the meaning of coordination as management of interdependencies. The fourth explores the increase in complexity and interdependence in the current scenario, through the VUCA concept (English acronym for volatility, uncertainty, complexity and ambiguity). The

* Oscar Mauricio Covarrubias Moreno, Professor of Public Policy, National Institute of Public Administration of Mexico (redoviti profesor javne politike, Nacionalni institut za javnu upravu Meksika, email: mauri@unam.mx)

ORCID: https://orcid.org/0000-0002-1240-725X 
fifth examines some challenges of global governance and coordination through the COVID-19 pandemic. Finally, it presents some conclusions.

Keywords: governance, interdependence, coordination, volatility, uncertainty, complexity and ambiguity, VUCA world

\section{Introduction}

Governance in various parts of the world faces important challenges that stem from two interrelated aspects. On the one hand, fragmentation and lack of coordination within and between governments, as well as between them and different social actors. On the other hand, the complexity of the great problems that affect well-being and threaten the future of society in the $21^{\text {st }}$ century, which are an expression of a world characterised by growing interdependence. In the first case, the decentralisation and privatisation of public services carried out in recent decades seem to have produced numerous single-purpose organisations with specialised roles and functions, authorities focused on themselves, and a lack of cooperation and coordination affecting the functioning of the government as a whole. In the second case, the complexity of social problems has raised the level of interdependence, since these are problems that no government can solve by itself and which require the coordination of multiple organisations and actors at the local and national level, but also globally.

This article is a general review of the literature on the VUCA model and its relationship with the field of governance and public administration based on growing interdependence and, consequently, coordination needs. Although it is true that it is a recent and still sparsely treated relationship, we believe that it could not only increase academic understanding, but also be a preliminary step to suggest avenues for future study.

The study is exploratory in nature and data has been collected from various documentary sources such as journals, research articles, organisational reports, government reports, media reports, and articles available on the web that helped guide the work. The article proposes that the VUCA (volatility, uncertainty, complexity and ambiguity) paradigm is a useful lens through which to look when thinking about governance challenges in terms of coordination. This is equally true for macro issues, such as the current COVID-19 crisis, and for the task of coordination at the national 
and local levels, because many of the complex public problems require coordinated solutions.

With this purpose in mind, the article is structured in six sections. After the introduction, the second section reviews the concept of governance in terms of coordination. The third section analyses the relationship between globalisation, coordination, and interdependence. The fourth explores the increase in interdependence in today's world, through the VUCA model. The fifth section examines some challenges of coordinated governance through the COVID-19 crisis. Finally, it presents some conclusions and findings. ${ }^{1}$

\section{The Importance of Coordination in Governance}

Coordination and governance are intertwined aspects that continually inform and contribute to each other. Coordination is a major issue for the effectiveness of any organisation, which is required at all stages of public policy or activities in the organisation. Coordination also supports coherent acts that have become a major governance challenge across the world (Begum \& Momen, 2019). Whole-of-government coordination mechanisms are fundamental to resolve divergences between sectoral priorities and policies, including external and domestic policies, and to promote mutually supporting actions across sectors and institutions (OECD, 2019).

Coordination is one of the oldest problems facing the public sector. As soon as government was sufficiently differentiated to have several organisations providing different services, or providing the same service in different ways, coordination became an issue (Bouckaert, Peters \& Verhoest, 2010). Although, as government structures begin to differentiate across ministries and departments, complaints arise, in the sense that organisations are unaware of what others are doing and that their programmes are, too often, contradictory, redundant, or both, it is no less true that the nature of contemporary government accentuates coordination difficulties. Today, public work involves complex configurations and interactions within governments, as well as in their relationship with their environment, through a variety of connections that influence the development of important government pol-

${ }^{1}$ It is important to mention that this article is complementary to the article "VUCA world and COVID-19 interdependence lessons" cited in the references, and published in November 2020. Both works have in common the reference to the COVID-19 crisis, because we believe that it is a global phenomenon that shows us interdependence and the need for greater coordination at all levels of government, from the local to the supranational. 
icies and programmes. The origin of these circumstances largely concerns decentralisation and globalisation as general determinants of the complex nature of contemporary government.

The convergence of both phenomena places important demands on the capacity of action of the states and governments that see their competences diminished, as well as the capacity to decide unilaterally and autonomously, both in the domestic sphere and with regard to their link with the outside. While the first produces a rethinking of the links between governments (central and local) and of those with the society, the second brings with it a progressive vulnerability to factors derived from the new world economic structures, as well as from the intervention of actors located beyond the borders.

From another angle, the increase in the need for coordination between governments has to do with the increase in interdependence, understood as the degree to which the institutions that belong to different governments must work together to achieve a common objective; that is, to face a problem that cannot be solved - or easily solved - by a government unilaterally (Agranoff \& McGuire, 2003), which is reflected in an expansion of areas of shared interest and common decision-making.

The above is related to the type of issues that they must face today. Public problems have become more complex in terms of size, intensity, and connectivity, affecting more people and more places. In many ways, this complexity can be summed up in the idea of a cross-cutting nature of problems that operates in three dimensions: spatial, causal, and temporal. In the first case, because the problems progressively ignore and transcend territorial or jurisdictional limits, in the second because, being the result of multiple causes or factors, they involve different sectors of public activity, and in the third, because many of the problems that are emerging or that have worsened, transcend, and cannot be solved in a single cycle of government. For Peters (2018), the appearance of difficult problems that cannot be easily solved through the actions of any individual public sector organisation is one of the factors that has exerted pressure for greater coordination.

Governments across the world are struggling to deal with "wicked policy problems", such as climate change, immigration, and crime. Wicked problems - those that are complex, intractable, open-ended, unpredictable seem to be proliferating (Alford \& Head, 2017; Head 2019). Wicked problems pose highly complex and ambiguous policy planning and development challenges, and also raise implementation and service-delivery problems that cannot be solved within one sector or by one administrative level alone, but require coordination between different actors, organisations, levels, and governments (Christensen \& Lægreid, 2018). These problems, which are 
sometimes rather vaguely characterised as "wicked problems", require substantially greater coordination efforts than relatively moderate problems that clearly fall within the domain of a single government organisation.

Whatever the specific pressures that lead to globalisation, they generally increase the demands on governance. In the opinion of Klingner (2015), governance means a greater capacity of governments to gather resources and coordinate authorised responses at the national and international level. In developed countries, this typically means maintaining the capacities of governments to coordinate policy, collect information, provide services through multiple (often non-governmental) partners, replace hierarchical bureaucracies with more flexible mechanisms, as well as resolve performance and accountability problems caused by interactions between sectors and levels of government.

In today's world still struggling with the long tail of the global economic crisis, many policy-makers lament a situation that has become "ungovernable", either because of a lack of leadership or because of a lack of adequate governance, or both. Problems have become increasingly global while governments have remained national. The world, in short, is in search of good governance (Dupont, 2013). At the international level, a governance approach is required that paves the way for better coordination mechanisms which accelerate mutual learning and transfer of skills. A higher level of coordination and collaboration between governments could unleash new investments in effective mechanisms for multinational governance (Mazzucato \& Kattel, 2020). At the global level, governance encompasses activities that transcend national boundaries at the international, transnational, and regional levels and is based on the rights and rules that are enforced through a combination of economic and moral incentives. Mechanisms of global governance are composed of elements and methods from both the public and private sectors. These elements include agreed upon standards, evolving norms based on shared values, and directives issued by private authorities and ultimately enforced by states. Methods of global governance include harmonisation of laws among states, international regimes, global policy issue networks, and hybrid institutions that combine the functions of state agencies and private sector organisations (Kennette, 2015).

Governance is considered essential to achieve the United Nations' Sustainable Development Goals (SDGs), such as ending poverty in all its forms, ending hunger, achieving food security and improved nutrition, and promoting sustainable agriculture. This is to guarantee a healthy life and promote well-being for all people. Goal 17 precisely refers to the fact that the SDGs can only be achieved with solid global partnerships and coopera- 
tion (United Nations, 2015). Successful implementation of a development agenda requires inclusive global, regional, national, and local partnerships on principles and values, as well as a shared vision and goals that focus first on people and the planet. And this implies coordination and coherence.

Recommendation of the Council on Policy Coherence for Sustainable Development (PCSD) of the OECD (2019), focuses primarily on the enablers that are essential to facilitate governments' efforts to enhance PCSD. It is based on the premise that the ability to consistently develop and implement coherent policies in all areas is dependent on the processes, systems, structures, and tools used by governments to manage and coordinate policy at all levels. For the purpose of this Recommendation, the Policy Coherence for Sustainable Development (PCSD) is an approach to integrate the dimensions of sustainable development throughout domestic and international policy-making. Its objectives in the context of the 2030 Agenda are to advance the integrated implementation of the 2030 Agenda by: (i) fostering synergies and maximising benefits across economic, social and environmental policy areas; (ii) balancing domestic policy objectives with internationally recognised sustainable development goals; and (iii) addressing the transboundary and long-term impacts of policies, including those likely to affect developing countries.

Governance refers to the process or set of actions by which the government directs or leads the society. This entails the definition of common objectives, a sufficient social acceptance of them, a direct or indirect participation of the community in the realisation of common objectives, as well as a coordination of the multiple actions of social actors to enable and ensure their realisation (Aguilar, 2011). Leading a society is achieving the coordination of a diversity of actors, and coordination cannot be achieved through command and subordination, nor through an invisible hand, but rather through deliberate interactions between governmental and extra-governmental actors who, in order to achieve their ends, must consider the ends of others and exchange information and resources.

The government is one of the actors in governance, while the other actors involved in it vary according to the level of government. In rural areas, for example, other actors may include farmers' associations, cooperatives, NGOs, research institutes, religious leaders, financial institutions, political parties, the military, etc. The situation in urban areas is much more complex. At the national level, in addition to the above actors, the media, pressure groups, international donors, multinational corporations, etc. can play a role in decision-making or influence the decision-making process (UN, 2009). 
At this point, it is convenient to refer to the principles that should guide "good governance" which are inherent to the rule of law, such as participation, consensus, responsibility, transparency, responsiveness, effectiveness, efficiency, equity and inclusion. What makes governance more effective, more legitimate and more sustainable, has to do precisely with the principles of the rule of law, which ensure that corruption is minimised, the opinions of minorities are taken into account, and the opinions of minorities are heard, voices of the most vulnerable in society in decision-making (UN, 2009; WEF, 2013).

Governing in contemporary social conditions implies recognising the interdependence between the different actors who have key resources to achieve the desired goals of life in common. In a context of growing interdependence, the government loses the ability to make unilateral and sovereign decisions in a significant number of public interest problems, which forces it to dialogue and agree with extra-governmental actors.

The recognition of governmental insufficiency for the governance of a society and, therefore, the need for the association and coordination of the government with organisations external to it, constitutes a relevant contribution to the concept of governance to political action and political explanation. Governance then takes the form of the coordination of collective action rather than the subordination of independent actors.

Designing a sustainable multi-stakeholder initiative to address a complex, sometimes global problem, requires what the World Economic Forum (WEF, 2013) document More Effective Design of International Initiatives - Coordinated Governance calls "effective coordinated governance", which occurs when public and private actors from various states align their efforts to implement an agreed solution to a common or global transnational problem, and do so in accordance with the guiding principles and fundamental norms that guarantee that such governance is generally considered legitimate The concept is different from the traditional model of governance based on the agreement between sovereign states. It also addresses possible weaknesses in other approaches to address the shortcomings of the traditional model. In summary, the perspective of "coordinated governance" can provide leaders and senior officials with a framework to help improve existing initiatives and plan for new ones.

Despite the existence of important nuances in the interpretation and application of the essential tasks that the state must assume, its importance as a subject and context of social coordination is no longer under discussion; the questions right now revolve around the questions of what it can 
and cannot do, and how it should do it. Where there seems to be no doubt is the fact that although nation-states have lost the capacity for unilateral and autonomous decision-making, they will continue to be the essential horizon of reference, the political arena, and the decisive institution to face problems of articulation, social and government, to which we have alluded. However, it seems that this can only be achieved in active mutual collaboration, both with their own localities and regions, as well as with entities and actors from the external environment.

In the contemporary context, a diversity of actors is involved in the decision-making process or in any political action. Therefore, it is the synchronised actions of the government that determine the acts of coherence and support the government's political agenda (Tamtik, 2016). Thus, coordination is an essential component of coherent public interventions that also represent a major governance challenge throughout the world.

Based on the aforementioned considerations, for the purposes of this article, we understand coordination in governance as a complex task of an essentially political nature, essential for joint government action which, through means of formal and informal agreement, has to do with the tuning and organisation of scattered efforts, the reconciliation of interests and autonomies, the harmonisation of action methodologies, as well as the management of interdependencies in the different scenarios of government activity; that is, within and between units, sectors, levels of government, as well as in the interaction with social actors and international entities. Likewise, we also recognise that achieving collective action does not lie solely in coordination. Especially if the coordination is not based on the existence of public administrations with institutional intervention capacity. In other words, internal sufficiency and external connectivity are two key factors associated with effective governance.

\section{Globalization, Coordination and Interdependence}

Interdependence exists when two or more actors are dependent on one another. Dependence can mean many things, of course, but in social theory, it is most usually defined in terms of resources: an actor is dependent on another actor if it cannot realise its aims without the resources of another actor. The relevant actors might be individuals, organisations, or even states. The goals are whatever these people or groups want to 
achieve. The resources can include physical and financial ones, but also knowledge and skills, as well as moral resources including legitimacy, and also time and effort. So, interdependence is a relationship in which various actors all need access to each other's resources if they are to attain their goals (Bevir, 2009).

The need to address common issues and therefore mutual dependence has been present in the government since its origins. However, obviously, in current times it has increased significantly. The growth of issues to be addressed in the intergovernmental arena, both regionally, nationally and even internationally, is unprecedented, and is expected to continue to grow, spreading to new areas of public policy. In the contemporary world, local and national problems increasingly have to do with the factors and decisions that come from faraway places. These realities are gaining presence in the world and becoming more interconnected, at different scales: local, regional, national, and global. One of the biggest changes in politics since the late $20^{\text {th }}$ century is the extent to which the public policy agenda is not established or defined within the national borders.

The political system also operates within what Wallerstein (2005) calls the "modern world-system". As a result of the growing ties of interdependence that affect nearly everyone, the world has become a single social system. The term "globalisation" is widely used to refer to the growing interdependence of the world society. Giddens defines globalisation as "action at a distance", with which he refers to the reorganisation of time and space in our lives. In other words, our lives are increasingly influenced by the activities and events taking place far from the social contexts in which we conduct our daily activities (Giddens, 1989).

The process of globalisation has made the nations and peoples of the world increasingly interdependent in many ways. Globalisation is inextricably linked with interdependence since the available resources are unequally distributed across the world and for that matter, no country can claim to be fully served with regard to all the resources it needs to be totally self-sufficient. The need for countries to rely on each other for these resources creates a global interdependence (Paehlke, 2009; Bentil, 2016). As Streeten (2001) pointed out, interdependence exists when one country by unilateral action can inflict harm on (or provide benefits to) other countries. Competitive protectionism, devaluation, deflation, or pollution of the air and sea beyond national boundaries are examples. Interdependence, in the words of Barber (2004), means that the borders no longer mean very much, and that people and countries already are dependent on 
one another. He affirms that if nations do not start thinking that way, we are not going to be able to deal with such devastating challenges as AIDS, drugs, illegal immigration, disappearing jobs, global markets, terrorism or, for that matter, much of anything else. There is almost nothing in life that does not depend, one way or the other, on people someplace else. That goes for the things we like, and the things we fear. Aryeetey and Dinello (2007) refer to global interdependence as an incarnation of the butterfly effect, which may ultimately suggest how to limit globalisation's negative aspects and how to ensure that it is a constructive phenomenon.

Global interconnectivity has serious implications for public policy. Interdependence means that each participant and each point in the social process are affected by the context in which they are framed (Lasswell, 1970). Thus, the establishment of the agenda and defining the problems no longer occur within a purely national context. According to Parsons (2007), the strength of the Eastonian "black box" approach that defines the political system as rather limited to the national level is less consistent than it might have been in the past. The boundaries of the political system are not impervious to external pressures and influences.

Social problems are more complex in terms of size, intensity, and connectivity. This complexity can be summarised in the idea of a cross-cutting nature of problems, which operates simultaneously in three directions: spatial, multifactorial, and temporal, creating significant challenges for policy design (Covarrubias, 2014). With the notion of cross-cutting issues, we seek to emphasise the fact that public issues increasingly cross borders, which have traditionally served as references for government action. In the spatial sense, because more and more the problems cross jurisdictional and territorial limits; in the functional sense, because they involve different sectors of public activity; and in the temporal sense, because problems that are emerging or have worsened cannot be resolved in a single cycle of government.

Interdependence has to do with the degree to which institutions belonging to different governments, of the same or different levels, must work together to achieve a common goal. The level of interdependence that characterises any particular problem will influence the government's ability to solve the problem. Importantly, Peters (2005) notes that political requirement for coordination, as management of interdependencies, will mean that the most interdependent problems are likely to be more difficult to solve. Therefore, the effectiveness of the final decision-making process will depend on the capacity for interaction and negotiation, intraand intergovernmental. 
In the different domains of public activity, the need for coordination can be seen within and between government organisations, between the government and citizens, as well as between public organisations and the private sector. Depending on the nature of the organisations and actors involved, coordination scenarios can be sectoral, intersectoral, intergovernmental, and international (bilateral and multilateral). On the other hand, the coordination requirements are directly proportional to the level of interdependence, as well as to the number and type of institutions responsible for intervening in a specific public issue.

Governance, in terms of coordination and interdependence, implies recognising the existence of spaces of self-government and shared government. The first one represents those jurisdictions where governments have exclusive powers to regulate and manage a part of public affairs, which is related to the possibilities of governments to act effectively on their own or unilaterally, in addressing a public issue. While the shared government area represents the jurisdictions in which organisations from different governments must work together to achieve goals of mutual benefit, it is an expanding form of governance whose presence is gaining recognition in legislation. Shared government does not replace self-government, but rather recognises and integrates it. As an equation, the above could be represented as follows: shared government $=$ self-government + coordination (see Covarrubias, 2011). The diversity of arrangements is such that the synthesis of self-rule and shared rule can be achieved in different ways. There is a defined relationship between the degree of interdependence and the level of self- and/or shared governance. The proportion of one or the other is in direct ratio to the degree in which institutions that belong to different governments with the same or different level must work together to achieve a common goal. This means that the relations of governments are crucial in the implementation of policies concerning the treatment of problems or issues of cross-cutting nature, which cannot be solved other than in a coordinated manner.

From the above, at least the three following points can be inferred: (i) due to their complex nature, current public problems increasingly exceed jurisdictions and political and administrative capacities, expanding areas of common decision; (ii) thus, despite the existence of formal autonomy between governments, the reality is that "mixed jurisdictions" and areas of interaction are gaining importance and therefore, the need for cooperation is unavoidable; and (iii) the effectiveness of governance will increasingly depend on the level of coordination that makes possible collaboration based on strengthening self-government, and simultaneously 
on the development of co-government mechanisms at both the national and international levels.

As we will see in the next section, in a VUCA environment of growing interdependence, effective governance means that moving from self-referential policy-making to the one supported by coordinated processes is not an option, but an essential need for governments and their organidations.

\section{VUCA: A More Complex and Interdependent World}

Regardless of whether we accept the concept of the VUCA environment or not, currently public, private, and social organisations around the world must operate and face unprecedented challenges in an increasingly volatile, uncertain, complex and ambiguous global environment: the COVID-19 crisis is a dramatic example (Covarrubias, 2020). VUCA and COVID can be used synonymously for our seriously disrupted contexts. Don't forget though that COVID-19 is only one of the many current examples of VUCA in our world (UGM, 2020).

Although disagreement with the concept may lie in the argument that the elements represented by VUCA have existed for decades (see Skapinker, 2018), this does not cancel the essence of it. VUCA, an acronym for volatility, uncertainty, complexity, and ambiguity, was coined by the United States military in the early 1990s, to describe what the world would be like at the end of the Cold War with the collapse of the Soviet Union, anticipating with this the appearance of a complex, confusing, and diverse global landscape, instead of a simple, clear, and monolithic one.

What makes VUCA so interesting at the present time is the simultaneous focus on each of the components and the interaction between them, especially when, over a long period, the aspects of VUCA were studied in isolation. Boulton and colleagues (Boulton, Lindsay, Franklin \& Rue, 1982) argued that uncertainty and the environment should be analysed separately. Ettlie, Bridges and O'Keefe (1984) investigated and analysed uncertainty in relation to the organisational environment, but did not take into account the effects of complexity and ambiguity; in essence, these latter aspects were minimised or ignored. One of the reasons for this lack of integration in the investigation of VUCA factors is that there has often been confusion about the meaning or practical interpretation of them, 
that is, in the way in which they can be operationalised and addressed in terms of strategy and management.

VUCA combines four different types of challenges: volatility, uncertainty, complexity, and ambiguity that require four different types of responses. The VUCA framework well encapsulates the challenges individuals and governments face in these volatile and uncertain times. The framework also outlines the approach one should take, with due consideration of the amount of information available and the certainty of the situation (see Bennett \& Lemoine, 2014; Ng et al., 2020).

- Volatility. The term refers to the quality or condition of something or someone, of being volatile, such as a) a tendency to change rapidly and unpredictably (price volatility, stock market volatility), and b) a tendency to break out into violence or anger (volatility of the region, volatility of temperament). Thus, a volatile environment or situation is one that can change rapidly and unpredictably, especially for the worse.

- Uncertainty. It refers to the quality or status of something or someone considered uncertain or doubtful or unreliable which generates a feeling or attitude that one does not know the truth. Among the words related to uncertainty are: distrust, doubt, suspicion, and skepticism (Merriam Webster, 2020).

- Complexity. The word complex lives up to its name, as it contains multiple meanings being an adjective, noun and verb. Of the various meanings of the term complex, we highlight for our purpose the one that refers to "a set composed of complicated or interrelated parts", as well as that of a group of related units of which the degree and nature of the relationship are imperfectly known, or the sum of factors that characterise a certain state of affairs or a situation (Merriam Webster, 2020). As a verb, its meaning is to unite. Complex comes from the Latin complecti, which means "to entwine, embrace" or "to braid".

For the OECD (2018), volatility is related to rapid and unpredictable change. Stock markets, for example, are considered volatile due to how quickly they change and are therefore notoriously challenging to predict. Uncertainty is related to the quality of the information that is available, or the degree to which the outcome of an event is known in advance. Complexity increases when there is a greater number of variables or relevant interrelations; the greater the number of variables, the more complex a situation is. And, ambiguity occurs when an event, situation, or context 
is unclear, either because information is missing, inconsistent, contradictory, or hidden in some way. For humans, each of these components of VUCA creates a less predictable world.

The use of VUCA was soon adopted in the business, government, and academic spheres as a reflection of the advent of a "new normal" characterised by global and untimely changes that would bring with them a series of new challenges and uncertainties. A good example of this was the financial crisis of 2008-2009, which made many business models obsolete, and through which important organisations throughout the world were abruptly immersed in turbulent circumstances (Lawrence, 2013). Alongside technological development, vast and abrupt changes continued to occur, social media detonated, the world's population continued to grow and age simultaneously, and global disasters disrupted lives, economies, and businesses, just as is currently the case with the COVID-19 pandemic.

Friedman (2005) warns that the current exchange rate is very different from the past. In the current flattening process, the world shrinks "from a small size to a smaller size" and at the same time gets flattened. This rapid flattening continues to create the so-called VUCA environment which represents the volatility, uncertainty, complexity and ambiguity that combine and generate an increasingly unstable and rapidly changing world.

For the OECD (2018), labour markets and financial systems are increasingly interconnected, which means that it is increasingly difficult to identify the causes and effects of complex problems. For example, the impact of a transformative referendum, to say the least, as Brexit seemed unlikely, on both the UK and Europe (and indeed the rest of the world) is almost impossible to predict, but certainly will be deep. The public sector as a whole is competing with VUCA, even if public administrations and their managers do not understand how, where, and why.

In this context, we should bear in mind the warning of Emmert, Crow and Shangraw (2006), in the sense that it should not surprise us that organisational and social structures and processes would become increasingly complex. This complexity is driven by various forces, including a growing interdependence between organisations and sectors, technological change, greater demands on organisations, and the globalisation of interactions: "The greater interdependence between levels of government, various agencies, the public and private sectors and even between nation-states will add a new expansive of complexity to public organizations. Technical and social innovations are complicating rather than simplifying the character of government work." As we are witnessing today, the in- 
cessant increase in complexity is forcing government units, national and local, large and small, to operate in more complex, dynamic and uncertain internal and external environments. This will undoubtedly be a real challenge for political and governance structures, many of them anachronistic, built to meet the needs of a much simpler society.

In general terms, the isolated treatment of VUCA elements has prevailed, but increasingly, they are conceived as factors that overlap and interact in various ways. Some scholars have even included other elements, such as chaos in the VUCCA model (Ferrari, Sparrer \& Varga, 2016). From a UGM (2020) point of view, it is also useful to recognise that, while VUCA is the acronym that has stuck, it would probably be more accurately represented with C as the first letter (CUVA perhaps - though it doesn't have the same ring to it!). Complexity is at the core, with volatility, uncertainty and ambiguity among its key attributes. According to Borges (2019), volatility, uncertainty and ambiguity are sensations and reflections of the real. The reality is that we live in a complex world and consequently, the VUCA elements are a visual representation of complexity.

Although complexity is only one of the four VUCA elements, for our part, we also believe that it has primacy because it links or encompasses the other elements of the model: complexity is the cause of uncertainty and this, in turn, generates volatility and ambiguity. This can be explained from the concept of non-linearity.

From chaos theory, it has been pointed out that even when the relationships between the elements of a system can be expressed in deterministic terms, the future behaviour of a system cannot be predicted with certainty or precision. This is due to the non-linear relationships of the elements of the system. Thus, while linear relationships make certain and precise predictions possible, non-linear relationships do not. Non-linearity is the main source of uncertainty and makes the trajectory of the future behaviour of a system unpredictable (Morçöl, 2012).

In this order of ideas, it should be added that the increasing degree of complexity of the VUCA environment is the product of the synthesis between non-linearity and connectivity. From this perspective, complexity (non-linearity) and connectivity are the most appropriate words to refer to the new situation behind the VUCA world, precisely because both refer to the causes and not to the symptoms.

In short, the elements represented in VUCA denote that we are entering an era of more dramatic change in several centuries. This change is irresistible and infectious. It will spread to every corner of our lives, to our 
businesses, our bank accounts, our hopes, and our health (Ramo, 2009). It means that we will continue to face an avalanche of incessant and dislocating change.

In the $21^{\text {st }}$ century, the interdependence and disruptive forces that converge in VUCA cannot be better represented than by the crisis caused by a tiny agent, about 0.000125 millimetres, located perhaps in a market in Wuhan, a populous city in the Hubei province, China. The SARS-Cov-2 virus, which causes the COVID-19 disease, has put the entire planet in check. In less than three months, this microscopic pathogen slowed down trade, travel and industry, placing the global economy in its most critical moment since the 2008 financial crisis.

The interdependence and fragility of our modern society with its underlying socioeconomic systems increase the risks of the global pandemic. According to the Copenhagen Institute for Futures Studies (CIFS, 2020, p. 4), the first businesses to be affected outside of the original epicenter in Wuhan were those with global supply chains when products stopped flowing. When people stopped travelling, airlines, airports and hotels followed. When our social habits became too rigid for voluntary adjustments, bars, cafes, restaurants also had to close. Since then, it has been a domino effect with companies affected and jobs lost and at risk.

Based on Scharmer (2020), we can say that COVID-19 has become one of the most effective and impactful teachers of our VUCA time. It gives us an advanced lesson on systems thinking and interdependence with the 7.8 billion citizens of the planet as students. Some of us have already learned these lessons intellectually, but now we are seeing it in a dramatic way. We are part of the same global network of social, economic, cultural, and environmental connections. Let us hope, then, that human beings come out of this crisis more aware of the problems of sustainability (Basu, Basu \& Tapia, 2020).

On the iconic cover of The New Yorker magazine from 23 March 2020, Christoph Niemann addresses the spread of the new coronavirus, evoking a world in which the health of an individual and the health of the world appear to be increasingly interdependent. Its image reflects both isolation and interconnection (Mouly, 2020). Niemann alludes to the chain reaction of COVID-19, using the metaphor of the sneeze effect on a world full of dominoes that fall in a non-linear sequence.

Without a doubt, COVID-19 has reminded us of our fundamental condition of fragility of biological beings vulnerable to the same types of disease pathogens that infected and killed our ancient ancestors. From cholera to 
COVID-19, these pathogens now have a global reach, due to our more interconnected and interdependent way of life, which makes contagious diseases increasingly common and widespread. In just a few months, COVID-19 went from a discrete localised outbreak to a raging global pandemic (CIFS, 2020). The speed and scale of the spread, the severity of the cases, and the social and economic disruptions have been dramatic, as will be its effects in the short and long term.

Volatility, uncertainty, complexity and ambiguity are now the norm, not just risks. The world seems to operate by a new set of rules that are difficult to observe directly. This requires a new mindset that acknowledges uncertainty as part of everyday decision-making. It also calls for the understanding that there is path dependency in all of our public sector institutions and policy interventions which may not serve us well, or worse, lead to predictable outcomes (OECD, 2017). The interconnection and interdependence that characterises the VUCA environment are global in scope, broad in spectrum and, in many ways, involving nature, since just as we depend on others in practically all areas of human activity, our own actions affect others like never before.

\section{COVID-19: A Call for Coordinated Governance}

Based on the previous sections we can affirm that one of the main lessons of the COVID-19 pandemic is the reiteration that, like other issues such as environmental degradation, organised crime, human trafficking, terrorism, irregular migration and refugees, social marginalisation, greater occurrence of natural disasters and endemic diseases, to name a few, are part of a series of emerging problems that are increasingly overwhelming the capacity of governments and that demand fundamental changes in the paradigms that have guided the study and practice of governance.

These types of problems are transboundary in their impacts, and the solutions require participants and resources from multiple countries. However, traditional governance structures are based on the system of nation-states, each with its own territorially delimited powers. The nation-state system requires states to act by consensus if they wish to effectively address a shared problem that transcends their individual borders (WEF, 2013).

A common element of all these issues is that, although policy responses are legislated within national jurisdictions, they must be developed and 
implemented in concert with other national governments and considering other contexts and policy arenas to be effective (Andrews \& Whyte, 2018). These types of issues require governance capable of bringing together a variety of actors from business, civil society, and government agencies across geographic, cultural, and other boundaries.

This poses a serious challenge to traditional governance arrangements in many states. Changing the dynamics of a well-established and complicated public sector is not easy. A new and necessarily complex process of seeing, understanding, and deciding fundamentally challenges our institutions; these are the makings - the foundational conditions - of a governance crisis. Our $19^{\text {th }}$ century institutions are outmoded by $21^{\text {st }}$ century problems stemming from interconnectivity and interdependence. Traditionally, public policy makers have dealt with social problems through discrete interventions that are layered on top of one another (OECD, 2017). However, these may shift consequences from one part of the system to another, or continually address symptoms while ignoring causes.

Epidemics are a reality test for public governance and leadership, not only at country level, but also at regional and continental levels, as well as in connection with the wider network of multilateral actors and partners (Mo Ibrahim Foundation, 2020). What started as a one-dimensional health crisis quickly turned into a socio-economic, humanitarian, and political crisis around the world. The crisis is no longer one-dimensional or unique to health. While the cure for COVID-19 on an individual level is a vaccine, the solution to the impacts of the crisis and the problems generated is related to governance in different dimensions (Acuòa, 2020). Although the virus affects all societies regardless of the levels of human development or political preference, its consequences are harsher for the most vulnerable. The economic fallout is not entirely a direct outcome of the COVID-19 pandemic but a result of how we have responded to it - what measures governments took and how ordinary people, workers, and firms reacted to the crisis (Basu, Basu \& Tapia, 2020). Thus, for most societies, it is no longer about reactivation or recovery, but about rebuilding. The world has changed and, therefore, the governance responses to the crisis must be different if the expectation is to build a "new normal better".

Thus, one of the new manifestations of the ineffectiveness of governments has to do with the disarticulation and incoherence of their actions, with the lack of coordination between policies to face a series of complex problems, whose pernicious effects increasingly affect the well-being and future of the society as a whole. To face the new generation of social 
problems, greater coordination within and between governments will be necessary, but not just any type of coordination, rather a coordination that can only come from a systemic and global vision with a vision of the future.

In the face of COVID, as Mazzucato, Cherif and Hasanov (2020) point out, a comprehensive systems-level perspective is required, particularly when it comes to "wicked issues" such as public health crises and climate change, which involve a wide range of complex socio-economic and technological issues. To be truly effective, any such programme must be designed to build systemic resilience and public value.

When there is the will to act, globalisation becomes a political imperative, precisely because of the complex interdependencies involved between the local, national and international levels (Andrews \& Whyte, 2018). COVID-19 is a problem that cannot be addressed only at the nation-state level; it requires a global response, that is, the achievement of increased political convergence at the supranational level. The imperative to generate supranational responses to shared global problems has given rise to the concept and practice of "global governance" which, as Evans (2009, p. 256) points out, is part of the assumption that certain public policy problems cannot be addressed only at the level of the nation-state, but require a global response. Global governance, therefore, refers to the process of political interaction aimed at solving problems that most affect a state or region. As a global problem, the COVID pandemic requires governments to work in coordination. However, countries are fighting their own individual battles against the coronavirus, and in their own way from their national silos.

The United Nations (2020) points out that no country alone can overcome the pandemic caused by COVID-19. Responding to the significant economic and human effects of this disease, and promoting concrete solutions for the development emergency, require international cooperation and external financing. Solidarity worldwide is not only a moral imperative, but also a matter of interest to all. Most developing countries do not have sufficient national resources and fiscal space to finance a response to COVID-19 and adequate recovery measures.

With regard to this problem of the lack of coordination and cooperation between countries, the Director-General of the World Health Organization, Tedros Adhanom, called for international unity to fight the pandemic. With tears in his eyes, Tedros said the true enemy was not the virus itself but "the lack of leadership and solidarity at the global level and 
national levels". "How difficult is it for humans to unite to fight a common enemy that's killing people indiscriminately?" he asked at a briefing in Geneva. "Can't we understand that the divisions or the cracks between us actually are to the advantage of the virus?" "The best way forward and the only way forward is together", Tedros said (WHO, 2020).

Of course, each country has its own health systems, as well as its medical and technological resources, and the disease is at a different stage in each. But why is there still no internationally coordinated medical project equivalent to the "Manhattan Project" in wartime to mobilise all available global resources to discover a vaccine against the coronavirus and accelerate the cure.

There is a truly unprecedented race to develop a vaccine against SARS$\mathrm{CoV}-2$, with at least 44 vaccines in early development. However, as the epidemiologist Berkley (2020), Head of Gavi, the Vaccine Alliance sponsored by the World Health Organization, UNICEF and the World Bank, warns, if we want to maximise the chances of success and have enough doses to end the pandemic of COVID-19, current partial efforts will not be enough. If ever there was a case for a coordinated worldwide vaccine development effort using a great global scientific approach, it is right now. Ideally, this effort would be led by a team with the highest quality scientific advice mechanism that could operate under the auspices of the World Health Organization. But none of this will be possible without political will and the global commitment of the leaders of countries and multilateral organisations, and without collaboration on an unprecedented scale. A pandemic of this magnitude, affecting so many lives, livelihoods and economies, demands it.

Several vaccines may be on the cusp of approval, but it will be a year at least until they are widely available in much of the world. High-income countries have already reserved the first nine billion or so doses of the leading vaccine candidates through direct bilateral deals with pharmaceutical companies. Rich countries have not just pushed to the front of the line to secure preferential access for their populations. Developing a vaccine is just the first step in a long journey toward ending the pandemic, however. Even more daunting tasks await policy makers and health workers after pharmaceutical companies ship the first doses out the door. Given that only an estimated ten percent of the world's population has had COVID-19 to date, that leaves an extraordinarily high target for global vaccination efforts (Michaud \& Kates, 2020). Achieving this will take an astonishing feat of global cooperation, one that may prove more difficult and take much longer than most people realise. However, national 
leaders still seem unable to apply or even absorb the harsh lessons that crises teach us, from the SARS epidemic and the Ebola epidemic to the financial crisis: that global problems need global responses, not just local and national.

As Morillas (2020) argued, the nation-state is re-emerging between the global and individual levels as the main guarantor of people's health and the entity coordinating crisis management. At the international political level, the relationship between the global and the national also swings like a pendulum. In the $21^{\text {st }}$ century thus far, new powers have been returning national interests to the heart of their foreign policies. It is in this context that the coronavirus seems to have swung the pendulum towards the national, and the EU is no exception. In the absence of joint directives, restricting mobility and confinement remain national competences. The measures taken in healthcare and the response to the pandemic diverge between EU states and sometimes within them, between central and regional governments. So while the nation-state is not being wholly strengthened by the coronavirus crisis, neither are we facing the definitive withdrawal of the global and supranational.

Thus, the nation-state has once again become the basic unit, and the pandemic has enhanced the role of the states showing how, despite everything, there are times when this instance of government becomes indispensable. However, the state has, like everything, many versions, some of them with an institutional capacity undermined by certain parties and certain ideas. Decades of privatisation, outsourcing, and budget cuts in the name of "efficiency" have significantly hampered the responses of many governments to the COVID-19 crisis. Effective governance cannot be conjured at will, as it requires investment in core public sector capabilities that make a difference in times of emergency (Mazzucato \& Quaggiotto, 2020).

It is clear that greater coordination is not only needed for effective global governance in an increasingly interdependent world. Today there is growing agreement that we need better and more responsible institutions, as well as a more equitable way of sharing the benefits of technological progress and globalisation (Acemoglu, 2020). Especially now that the world is beset by a pandemic, there is a growing awareness that our systems are too fragile and vulnerable for the challenges of the $21^{\text {st }}$ century. Even if many countries are far from reaching a consensus on what a better future would look like, acknowledging the problem is always the first step to building something better.

Despite the differences in the policies introduced in different countries and sometimes within the same country, the response to COVID-19 has 
involved actions by all levels of government and other public bodies and agencies, especially those responsible for health, civil protection, education, and social issues. It has also rested on the frontline role of local authorities as those who are the closest to citizens and their needs (Council of Europe, 2020). The effectiveness of the response to the COVID-19 emergency greatly depends on the level of coordination and cooperation between the different actors involved. In this context, coordinated governance implies coordination within each nation-state, as well as with other countries.

It is also clear that it would be much more effective and save many more lives to mount joint operations not only at the country level, but also at the supranational level. However, in the face of global challenges, as COVID-19 shows us, local responses predominate. Clearly, an ideology of "each for himself" will not work when the health of each of us inevitably depends on the health of all others.

\section{Findings and Conclusions}

From the discussion, it can be said that coordination is the synchronisation of efforts to improve effective governance. Coordination and governance are intertwined aspects that continually inform and contribute to each other. Therefore, an effective coordination structure should be placed as a basic component for the implementation of policies and programmes aimed at tackling social problems. Coordination and governance are intertwined aspects that continually inform and contribute to each other. Coordination also supports coherent actions that have become a major governance challenge in a world in which public problems are increasingly complex and interdependent.

Governments across the world are struggling to deal with policy problems that cannot be solved within one sector or by one administrative level alone, but require coordination between different actors, organisations, levels and governments. However, following a review of various literature, it can be concluded that, despite its enormous importance, there is a deficit of coordination in governance, both locally and globally. COVID-19 is a reality test for public governance and leadership, not only at country level, but also at regional and continental levels, as well as in connection with the wider network of multilateral actors and partners.

As we have suggested, addressing the new generation of complex public issues, such as COVID-19, will require not only greater coordination, but 
a type of coordination that can only be built from a comprehensive and global vision based on governments with sufficient institutional capacity. In the current VUCA context, internal sufficiency and external connectivity of governments will be two key factors of the new governance. In other words, coordination is not a panacea. Indeed, effective governance will require increasing coordination, but in combination with solvent governments to produce positive synergy.

We have also seen that the use of the VUCA model in public administration is incipient, but is beginning to increase due to the global crisis caused by the COVID-19 pandemic. So, regardless of whether we accept the concept of the VUCA environment or not, currently public, private, and social organisations around the world must operate and face unprecedented challenges in an increasingly volatile, uncertain, complex, and ambiguous global environment: the COVID-19 crisis is a dramatic example. Volatility, uncertainty, and ambiguity are reflections of the real, and the reality is that we live in a complex world, consequently, VUCA is a visual representation of complexity.

Finally, the VUCA paradigm is a useful lens through which to look when thinking about governance challenges in terms of coordination. This is equally true for macro issues, such as the current COVID-19 crisis, and for the task of coordination at the national and local levels because many of the complex public problems require coordinated solutions.

\section{References}

Acemoglu, D. (2020). The post-COVID state. Project Syndicate. Retrieved from https://www.project-syndicate.org/onpoint/four-possible-trajectories-after-covid19-daron-acemoglu-2020-06?barrier=accesspaylog

Alford, J., \& Head, B. (2017). Wicked and less wicked problems: a typology and a contingency framework, Policy and Society, 36(3), 397-413, https://doi.org/10 $.1080 / 14494035.2017 .1361634$

Acuòa, J. (2020). 7 ways COVID-19 is now a governance crisis. UNDP Latin America and The Caribbean. Retrieved from https://www.latinamerica.undp. org/content/rblac/en/home/blog/2020/7-ways-covid-19-is-now-a-governancecrisis.html

Agranoff, R., \& McGuire, M. (2003). Collaborative public management: New strategies for local governments. Washington, USA: Georgetown University Press.

Aguilar, L. F. (2011). Políticas públicas y transversalidad [Public policies and transversality]. In J. Ramos, J. Sosa \& F. Acosta (Eds.), La evaluación de politicas públicas en México [The evaluation of public policies in Mexico]. Mexico City, 
México: INAP-El Colegio de la Frontera Norte, https://doi.org/10.24965/ gapp.v0i5.445

Andrews, S., \& Whyte, J. (2018). Globalization and public policy. In A. Farazmand (Ed.), Global encyclopedia of public administration, public policy and governance (pp. 2604-2609). New York, USA: Springer, Cham, https://doi. org/10.1007/978-3-319-20928-9_1303

Aryeetey, E., \& Dinello, N. (2007). Testing global interdependence. Issues on trade, aid, migration and development. Global Development Network Series. Massachusetts, USA: Edward Elgar Publishimg, https://doi.org/10.7202/019312ar

Barber, B. (2004). Introduction. In S. Myers \& B. Barber (Eds.), Interdependence handbook: Looking back, living the present, choosing the future (pp. 8-9). New York, USA: The Interdependence Debate Education Association.

Basu, A., Basu, K., \& Tapia J. (2020). The complexity of managing COVID-19: How important is good governance? In B. Coulibaly, K. Dervis, H, Kharas \& Z. Qureshi (Eds.), Reimagining the global economy: Building back better in a post-COVID-19 world (pp. 87-95). Washington, USA: The Brookings Institution.

Begum, M. M., \& Momen, M. N. (2019). Coordination and effective governance. In A. Farazmand (Ed.), Global encyclopedia of public administration, public policy, and governance (pp. 1-6). New York, USA: Springer, Cham, https://doi. org/10.1007/978-3-319-31816-5_2000-1

Bentil, S. (September 6, 2016). Globalization and international interdependence. Retrieved from https://www.linkedin.com/pulse/globalization-international-interdependence-shadrack-bentil

Bennett, N., \& Lemoine, J. (2014) What VUCA really means for you. Harvard Bussines Review 92(1/2), 27.

Berkley, S. (2020). COVID-19 needs a big science approach. Science, 367(6485), 1407, https://doi.org/10.1126/science.abb8654

Bevir, M. (2009). Interdependence. In M. Bevir (Ed.), Key concepts in governance (pp. 115-117). Washington, USA: SAGE Publications Ltd, http://dx.doi. org/10.4135/9781446214817.n24

Borges, H. (August 26, 2019). Leading in complex times. From VUCA to complexity. Medium. Retrieved from https://helio-borges.medium.com/https-medium-com-hborgesg-leading-in-complex-times-6b583acf955

Bouckaert, G., Peters, B. G., \& Verhoest, K. (2010) Coordination: What is it and why should we have it? In G. Bouckaert, B. G. Peters \& K. Verhoest (Eds.), The coordination of public sector organizations. Public sector organizations (pp. 13-33). London, UK: Palgrave Macmillan, https://doi.org/10.1057/9780230275256_2

Boulton, W., Lindsay, W., Franklin, S., \& Rue, L. (1982). Strategic planning: Determining the impact of environmental characteristics and uncertainty. The Academy of Management Journal, 25(3), 500-509, https://doi. org/10.2307/256076

Copenhagen Institute for Futures Studies, CIFS (2020). Beyond the COVID-19. How the pandemic will shape our future? Retrieved from https://cifs.dk/publications/ 
Copenhagen Institute for Futures Studies, CIFS (2020). Pandemics. Existential risks and enablers of change. Retrieved from https://cifs.dk/publications/

Council of Europe (2020). Democratic governance and COVID-19. Retrieved from https://www.coe.int/en/web/good-governance/thematic-meeting

Covarrubias, M. (2011). The challenges of interdependence and coordination in the bilateral agenda: Mexico and the United States. In J. Meek \& K. Thurmaier (Eds.), Networked governance. The future of intergovernmental management (pp. 249-272). Los Angeles, USA: SAGE Publishing, https://doi. org/10.4135/9781483349473.n19

Covarrubias, M. (2014). The U.S.-Mexico border in the making of bilateral policy. In D. Klingner \& R. Moreno (Eds.), Using the Narcotrafico threat to build public administration capacity between the US and Mexico (pp. 179-192). New York, USA: American Society for Public Administration. CRC Press, https:// doi.org/10.1201/b16582-16

Covarrubias, M. (2020). VUCA world and lecciones de interdependencia COVID-19. GIGAPP Estudios Working Papers, 7(182-189), 513-532, https://orcid. org/0000-0002-1240-725X

Christensen, T., \& Lægreid, P. (2018). Governance coordination capacity and quality does wicked policy areas matter? Stein Rokkan Centre for Social Studies, Working Paper No. 5. July 21-27 2018.

Dupont, C. (2013). Governance under policy interdependence: Measuring performance and stimulating innovation. Global policy. Retrieved from https:// www.globalpolicyjournal.com/projects/hertie-governance-report/governance-under-policy-interdependence-measuring-performance-and-

Emmert, M., Crow, M., \& Shangraw, R. (2006). La gestión pública en el futuro: la postortodoxia y el diseòo de la organización [Public management in the future: Post-orthodoxy and organization design]. In B. Bozeman (Ed.), La gestión pública: su situación actual [Public management: The state of the art] (pp. 455-474). Mexico City, México: Fondo de Cultura Económica, https://doi. org/10.29265/gypp.v28i1.555

Ettlie, J., Bridges, W., \& O'Keefe, R. (1984). Organization strategy and structural differences for radical versus incremental innovation. Management Science, 30(6), 682-695, https://doi.org/10.1287/mnsc.30.6.682

Evans, M. (2009). Policy transfer in critical perspective. Policy Studies, 30(3), 243-268.

Ferrari, E., Sparrer, I., \& Varga, M. (2016). As being is to becoming, so is truth to belief. Simply More Complex: A SySt ${ }^{\circledR}$ Approach to VUCA. In O. Mack, A. Khare, A. Kramer \& T. Burgartz (Eds.), Managing in a VUCA world (pp. 2138). New York, USA: Springer, https://doi.org/10.1007/978-3-319-16889-0_2

Friedman, T. L. (2005). The world is flat: A brief bistory of the twenty-first century. New York, USA: Farrar, Straus and Giroux.

Giddens, A. (1989). Sociology. Oxford, UK: Polity Press.

Head, B. (2019). Forty years of wicked problems literature: forging closer links to policy studies. Policy and Society, 38:2, 180-197, DOI: 10.1080/14494035.2018.1488797 
UGM (2020). COVID-19: How The Virus Illuminates Our Vuca World. UGM Consulting. https:/ugmconsulting.com/COVID-19-How-the-virus-illuminates-our-VUCA-world.html (accessed December 2, 2020).

Kennette, B. (2015). Global governance in International Encyclopedia of the Social \& Behavioral Sciences (Second Edition), 2015. Pages 155-161.

Klingner, D. (2015). From local to global. In E. M. Guy \&. M. M. Rubin (Eds.), Public administration evolving. From foundations to the future (pp. 64-82). New York, USA: Routledge, https://doi.org/10.4324/9781315718958-4

Lasswell, H.D. The emerging conception of the policy sciences. Policy Sciences pp. 3-14 (1970).

Lawrence, K. (2013). Developing leaders in a VUCA environment. The power of experience, UNC Executive Development, UNC Kenan-Flagler Business School. Retrieved from https: https://www.emergingrnleader.com/wp-content/uploads/2013/02/developing-leaders-in-a-vuca-environment.pdf

Mazzucato, M., Cherif, R., \& Hasanov, F. (October 1, 2020). How to end the pandemic this year. Project syndicate. Retrieved from https://www.project-syndicate.org/commentary/universal-testing-to-end-covid19-pandemic-by-redacherif-et-al-2020-10

Mazzucato, M., \& Quaggiotto, G. (May 19, 2020). The big failure of small government. Project syndicate. Retrieved from https://www.project-syndicate.org/ commentary/small-governments-big-failure-covid19-by-mariana-mazzucato-and-giulio-quaggiotto-2020-05?barrier=accesspaylog

Mazzucato, M., \& Kattel, R. (2020). Covid-19 and public-sector capacity. Oxford Review of Economic Policy, 36(1), 256-269, https://doi.org/10.1093/oxrep/ graa031

Merriam Webster. Dictionary Merriam-Webster.com. Retrieved from https:// www.merriam-webster.com/

Michaud, J., \& Kates, J. (December 2, 2020). The dangers of vaccine disillusionment. Foreign Affairs. Retrieved from https://www.foreignaffairs.com/articles/ united-states/2020-12-02/dangers-vaccine-disillusionment

Mo Ibrahim Foundation (2020). COVID-19 in Africa: A call for coordinated governance, improved health structures and better data. Retrieved from https:// reliefweb.int/sites/reliefweb.int/files/resources/2020\%20COVID-19\%20 in\%20Africa.pdf

Morçöl, G. (2012). A complexity theory for public policy. London, UK: Routledge.

Morillas, P. (2020). Coronavirus: Between the global and the national. CIDOB. Retrieved from https://www.cidob.org/en/publications/publication_series/ opinion/seguridad_y_politica_mundial/coronavirus_between_the_global_ and_the_national

Mouly, F. (2020). Christoph Niemann's "Critical Mass". The New Yorker, March 16. Retrieved from https://www.newyorker.com/culture/cover-story/2020-03-23

Ng, Q. X., De Deyn, M., Loke, W., \& Chan, H. W. (2020). A framework to deal with uncertainty in the age of COVID-19. Asian Journal of Psychiatry, 54, 102263, https://doi.org/10.1016/j.ajp.2020.102263 
Organisation for Economic Co-operation and Development (2017). Systems approaches to public sector challenges. Working with change. Retrieved from: https://www.oecd.org/publications/systems-approaches-to-public-sector-challenges-9789264279865-en.htm

Organisation for Economic Co-operation and Development (2018). Future of education and skills 2030: Curriculum analysis. Retrieved from https://www. oecd.org/education/2030/Preparing-humanity-for-change-and-artificial-intelligence.pdf

Organisation for Economic Co-operation and Development (2019). Recommendation of the Council on Policy Coherence for Sustainable Development. Retrieved from https://www.oecd.org/gov/pcsd/recommendation-on-policy-coherence-for-sustainable-development-eng.pdf , https://doi. org/10.1787/9789264301061-7-en

Paehlke, R. (2009). Globalization, interdependence and sustainability. In Introduction to Sustainable Development - 1. Encyclopedia of Life Support Systems (EOLSS).

Parsons, W. (2007). Políticas Públicas [Public policy]. Mexico City, Mexico: Facultad Latinoamericana de Ciencias Sociales.

Peters, G. (2005). The problem of policy problems. Journal of Comparative Policy Analysis: Research and Practice, 7(4), 349-370.

Peters, G. (2018). The challenge of policy coordination. Policy Design and Practice, 1(1), 1-11.

Ramo, J. (2009). The age of the unthinkable: Why the New World disorder constantly surprises us and what we can do about it. New York, USA: Little, Brown and Company, https://doi.org/10.1177/0276146710395595

Scharmer, O. (April 9, 2020). A new superpower in the making: Awareness-based collective action. Medium. Retrieved from https://medium.com/presencinginstitute-blog/a-new-superpower-in-the-making-awareness-based-collectiveaction-83861bcb9859

Scharmer, O. (March 16, 2020). Eight emerging lessons: From coronavirus to climate action. Medium. Retrieved from https://medium.com/presencing-institute-blog/eight-emerging-lessons-from-coronavirus-to-climate-action$683 \mathrm{c} 39 \mathrm{c} 10 \mathrm{e} 8 \mathrm{~b}$

Skapinker, M. (2018). The empty consolation of "Vuca" and other buzzwords. Financial Times. Retrieved from https://www.ft.com/content/9aa465fe-d5e711e8-ab8e-6be0dcf18713

Streeten, P. (2001). Integration, interdependence and globalization. Finance and Development, 38(2), 34-37.

Tamtik, M. (2016). Policy coordination challenges in governments' innovation policy. The case of Ontario, Canada. Science and Public Policy, 44(3), 417427, https://doi.org/10.1093/scipol/scw074

United Nations (2009). Economic and social commission for Asia and the Pacific. What is good governance? Retrieved from https://www.unescap.org/resources/ what-good-governance 
United Nations (2015). La agenda de desarrollo sostenible. Naciones Unidas. Retrieved from https:/www.un.org/sustainabledevelopment/es/2018/06/ la-agenda-de-desarrollo-sostenible-necesita-un-impulso-urgente-para-alcanzar-sus-objetivos/, https://doi.org/10.4272/978-84-9745-511-4.ch2

United Nations (2020). La lucha contra el coronavirus es responsabilidad de todos. Retrieved from https://www.un.org/es/coronavirus/articles/lucha-contra-coronavirus-responsabilidad-de-todos, https://doi.org/10.20986/medpal. $2020.1083 / 2019$

Wallerstein, I. (2005). Análisis de sistemas mundo: Una introducción [World-systems analysis: An introduction]. Mexico City, México: Siglo XXI.

World Economic Forum (2013). More effective design of international initiatives Coordinated governance. Retrieved from http://www3.weforum.org/docs/ GAC/2013/WEF_GAC_InternationalInitiatives_CoordinatedGovernance Report_2013.pdf.

World Health Organization (2020). Director-General opening remarks at the member state briefing on the COVID-19 pandemic evaluation. Retrieved from https:// www.who.int/director-general/speeches/detail/who-director-general-openingremarks-at-the-member-state-briefing-on-the-covid-19-pandemic-evaluation--9-july-2020, https://doi.org/10.1093/ww/9780199540884.013.u39175

World Bank (2003). World development report 2003. Sustainable development in a dynamic world: Transforming institutions, growth, and quality of life. Retrieved from https://elibrary.worldbank.org/doi/pdf/10.1596/0-8213-5150-8, https:// doi.org/10.1596/0821351508_chapter3 


\section{COORDINATED GOVERNANCE IN THE VUCA SCENARIO}

\section{Summary}

This article is a general review of the literature on the VUCA model and its relationship with the field of governance and public administration based on growing interdependence and, consequently, coordination needs. Although it is true that it is a recent and still little treated relationship, we believe that it could not only increase academic understanding, but also be a preliminary step to suggest avenues for future study. The study is exploratory in nature and data bas been collected from various documentary sources such as journals, research articles, organisational reports, government reports, media reports, and articles available on the web that belped guide the work. The article proposes that the VUCA (Volatility, Uncertainty, Complexity and Abiguity) paradigm is a useful lens through which to look when thinking about governance challenges in terms of coordination. This is equally true for macro issues, such as the current COVID-19 crisis, and for the task of coordination at the national and local levels because many of the complex public problems require coordinated solutions.

Keywords: governance, interdependence, coordination, volatility, uncertainty, complexity and ambiguity, VUCA world 


\title{
KOORDINIRANO UPRAVLJANJE U PNSN SCENARIJU
}

\begin{abstract}
Sažetak
Članak je opći pregled literature o PNSN modelu i njegovoj vezi sa znanstvenim područjem upravljanja i javne uprave, utemeljenoj na rastućoj meduovisnosti $i$, posljedično, na potrebi za koordinacijom. Iako je točno da je ta veza recentna $i$ još uvijek slabo obrađena, vjerujemo da bi rad mogao ne samo povećati akademsko razumijevanje nego biti i preliminarni iskorak u buduća istraživanja. Priroda je studije eksploratorna $i$ podaci su prikupljeni iz različitib pisanih izvora - časopisa, istraživanja, organizacijskib, političkib i medijskib izvještaja kao i internetskih izvora. Rad sugerira da je PNSN (promjenjivost, neizvjesnost, složenost, neodredenost) paradigma korisna optika za promišljanje upravljačkib izazova u smislu koordinacije. Navedeno je jednako točno za velike izazove poput trenutačne COVID-19 krize, ali i za koordinaciju nacionalnib $i$ lokalnib razina jer mnogi složeni javni problemi zabtijevaju usklađena rješenja.

Ključne riječi: upravljanje, meduovisnost, koordinacija, promjenjivost, neizvjesnost, složenost, neodređenost, PNSN svijet
\end{abstract}

